\title{
ELECTROCHEMICAL BEHAVIOR AND DIFFERENTIAL PULSE VOLTAMMETRIC DETERMINATION OF CEFTAZIDIME, CEFUROXIME-AXETIL AND CEFTRIAXONE ${ }^{\dagger}$
}

\author{
UDC $543.552: 577.181$
}

\author{
Mara M. Aleksić ${ }^{*}$, Nikola Lijeskić ${ }^{2}$, Jelena Pantić ${ }^{2}$, \\ Vera P. Kapetanović ${ }^{3}$ \\ ${ }^{1}$ University of Belgrade, Faculty of Pharmacy, Department of Physical Chemistry \\ and Instrumental Methods, Vojvode Stepe 450, 11221 Belgrade, Serbia \\ ${ }^{2}$ University of Belgrade, Faculty of Pharmacy, Vojvode Stepe 450, 11221 Belgrade, \\ Serbia \\ ${ }^{2}$ University of Belgrade, Faculty of Pharmacy, Department of Analytical Chemistry, \\ Vojvode Stepe 450, 11221 Belgrade, Serbia
}

\begin{abstract}
The voltammetric behavior of three cephalosporins: ceftazidime, cefuroximeaxetil and ceftriaxone has been examined in $\mathrm{pH}$ range $2.0-8.0$ by cyclic voltammetry $(C V)$ and differential pulse voltammetry (DPV), using a hanging mercury drop electrode (HMDE). The effect of $\mathrm{pH}$ of the electrolyte solution and scan rate on the peak currents and peak potentials was examined. The nature of the electrode reduction process in acid solution was found to be diffusion controlled for ceftazidime and cefuroxime-axetil, but strongly influenced by adsorption in the case of ceftriaxone reduction. The adsorption and reorientation of the ceftriaxone molecule at the electrode surface caused instability of the voltammetric signal and disabled its determination in the acid medium. Ceftriaxone adsorption decreased with the increase of $\mathrm{pH}$, and at $p H>7$ the reduction process became diffusion controlled. Based on this study, DPV method was developed, validated and suggested for determination of ceftazidime at $p H$ 2.0, cefuroxime-axetil at $p H 3.5$ and for ceftriaxone at $p H$ 8.0. Linear concentration ranges, limits of detection (LOD) and quantification ( $L O Q)$ were determined. The method was applied for determination of cephalosporins in pharmaceutical dosage forms: Ceftazidime powder, Ceroxim tablets and Longaceph powder for injection solution.
\end{abstract}

Key words: Ceftazidime, cefuroxime-axetil, ceftriaxone, voltammetry, adsorption, determination.

Received November 13 $3^{\text {th }}, 2013$; revised December $13^{\text {th }}, 2013$; accepted December $17^{\text {th }}, 2013$.

${ }^{\dagger}$ Acknowledgement: This work was supported by the Ministry of Education, Science and Technological Development of the Republic of Serbia, Project No. 172033.

*Corresponding author: mara@pharmacy.bg.ac.rs. 


\section{INTRODUCTION}

Cephalosporins are antibiotics with a broad spectrum of antimicrobial and antibacterial properties. These compounds contain a $\beta$-lactam ring which is fused with a six-membered dihydrothiazine cycle bearing substituents attached to $\mathrm{C}-3\left(\mathrm{R}_{1}\right), \mathrm{C}-4\left(\mathrm{COOR}_{2}\right)$ and C-7 $\left(\mathrm{NHC}(=\mathrm{O}) \mathrm{R}_{3}\right)$. The cephalosporins: ceftazidime $(\mathrm{CFZ})$, cefuroxime-axetil (CFXA) and ceftriaxone (CTRX), whose structures are presented in Table 1, are second and third generation cephalosporin derivatives widely used in clinical therapy of severe infections [1-2].

Table 1 Chemical structure of investigated cephalosporins

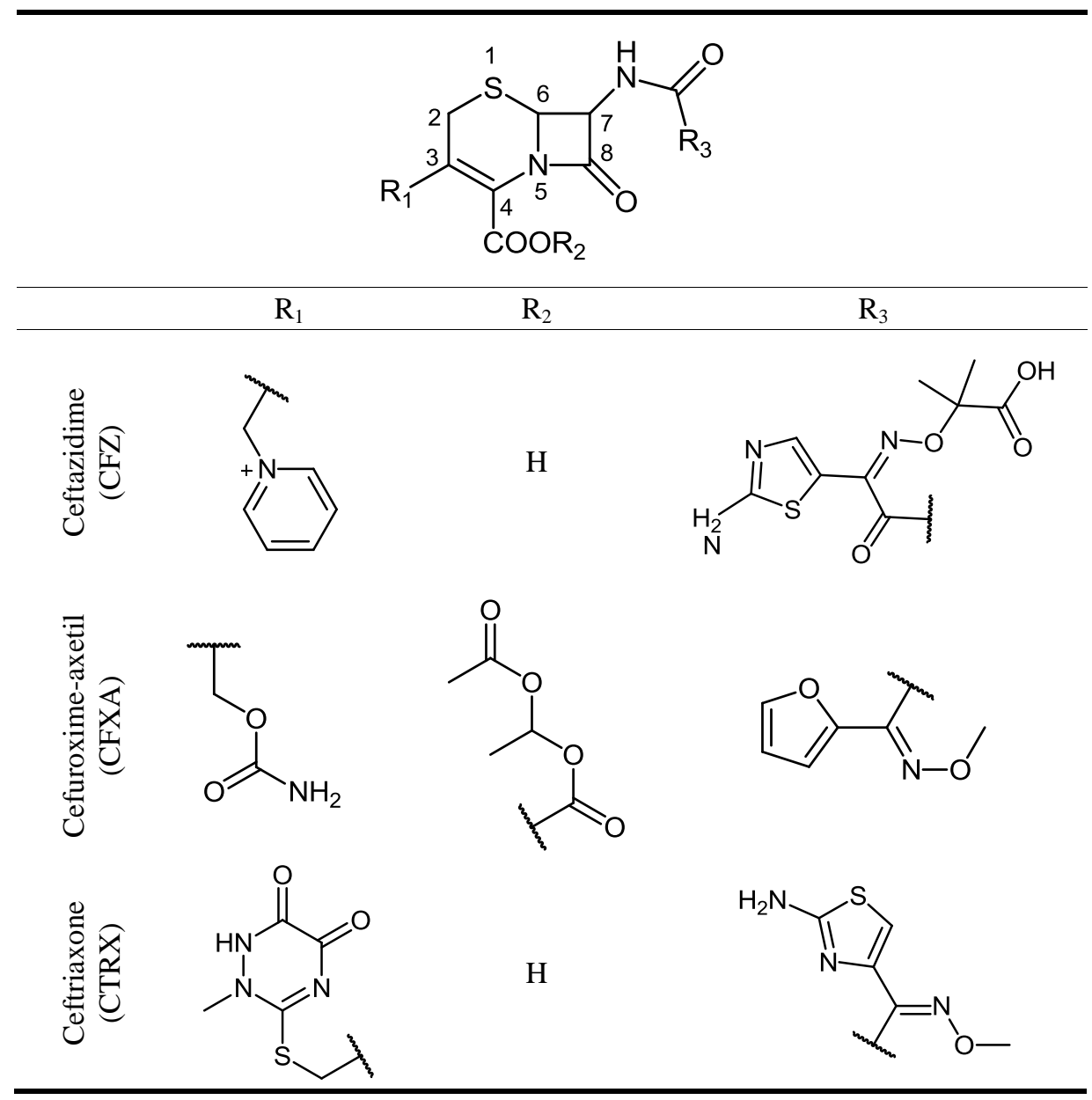

The "generation" classification is based on general features of the observed antimicrobial activity. Third generation cephalosporins are generally less active than the first-generation agents against Gram-positive cocci, but they are much more active against the Enterobacteriaceae, including penicilinase-producing strains. A subset of 
agents that belong to the third generation is also active against Pseudomonas aeruginosa [3]. Their activity is exerted through the inhibition of the biosynthesis of the bacterial wall, which leads to the lysis of microorganisms [4].

During the last two decades, a number of electroanalytical techniques for sensitive and selective determinations of a number of these antibiotics in pharmaceutical dosage forms or in biological fluids were developed [5-14]. Advantage of electrochemical procedures for analyses of drugs and biological material is that they often do involve only limited or no pre-separation, which would not only be time-consuming, but also a possible source of errors.

The reduction pattern of numerous cephalosporins at mercury electrode was reported by many authors [15-17]. Reduction of the methoxyimino group from the cephalosporin C-7 side chain is not adsorption free and can be preferably described as strongly influenced by the adsorption on the mercury surface. The reduction of the methoxyimino group occurs in two step pathway $[18,19]$ : the $\mathrm{N}-\mathrm{OCH}_{3}$ group is being protonated and than $\mathrm{N}-\mathrm{O}$ bond is cleaved, yielding an imine (1) which is subsequently protonated and reduced to an amine (2) as follows:

$$
\begin{gathered}
\mathrm{R}_{2} \mathrm{C}=\mathrm{NOCH}_{3}+2 \mathrm{H}^{+}+2 \mathrm{e}^{-} \leftrightarrow \mathrm{R}_{2} \mathrm{C}=\mathrm{NH}+\mathrm{CH}_{3} \mathrm{OH} \\
\mathrm{R}_{2} \mathrm{C}=\mathrm{NH}+2 \mathrm{H}^{+}+2 \mathrm{e}^{-} \leftrightarrow \mathrm{R}_{2} \mathrm{CHNH}_{2}
\end{gathered}
$$

However, in more acidic solutions the protonated form of cephalosporin can be reduced easier in a simple four-electron step to produce an amine (3).

$$
\mathrm{R}_{2} \mathrm{C}=\mathrm{NOCH}_{3}+4 \mathrm{H}^{+}+4 \mathrm{e}^{-} \leftrightarrow \mathrm{R}_{2} \mathrm{CHNH}_{2}+\mathrm{CH}_{3} \mathrm{OH}
$$

The occurrence of a single four-electron reduction peak is caused by the vicinity of the reduction potentials of oxime and intermediate imine.

Methoxyimino group is not the only electroactive site in these cephalosporin molecules. The unsaturated $\mathrm{C}=\mathrm{C}$ bond $(\mathrm{C}-3-\mathrm{C}-4$ position) is also reduced in twoelectron process [15], resulting in the presence of one additional cathodic peak at more negative potential.

Electrochemical properties of CFZ were investigated using differential pulse polarographic method [14], different voltammetric techniques based on its adsorption [20], using an indirect method based on adsorptive accumulation as a mercury salt [21], and with reactive accumulation on a poly-L-lysine modified mercury electrode [22]. Most of these methods used hydrolyzed CFZ in alkaline medium.

Electrochemical behavior of CTRX was often investigated [12,23-27], but certain number of difficulties in its determination is reported. All authors agree that CTRX is strongly adsorbed at electrode surface what may cause the instability of the signal in acid medium.

In contrast to CFZ and CTRX, there are no literature data about the CFXA electrochemical determination.

The aim of this work was to investigate the voltammetric behavior of selected cephalosporins, and to define the optimal conditions for their sensitive and precise differential pulse voltammetric determination. 


\section{MATERIALS AND METHODS}

\subsection{Instrumentation}

The voltammetric measurements were performed with a $\mu$ Autolab analyzer (EcoChemie, Utrecht, The Nederlands). A Metrohm 663 VA Stand was used with the threeelectrode system: hanging mercury drop electrode (HMDE) as working electrode, $\mathrm{Ag} / \mathrm{AgCl} / 3 \mathrm{M} \mathrm{KCl}$ reference electrode and glassy carbon (GCE) auxiliary electrode.

An Ultrasound bath and Radiometer pH meter, PHM 220, with appropriate standard buffer solutions were used.

The spectrophotometric measurements were carried out using a Cintra 20 spectrophotometer (GBC Scientific Equipment, Braeside, Australia) with $1.0 \mathrm{~cm}$ path length quartz cells. The solutions were scanned from $190 \mathrm{~nm}$ to $400 \mathrm{~nm}$ with spectral bandwidth of $1.0 \mathrm{~nm}$ and scan speed of $120 \mathrm{~nm} \mathrm{~min}^{-1}$.

\subsection{Reagents and solutions}

Standards of CFZ, CFXA and CTRX, were kindly donated by the Agency of Drugs and Medical Devices, Belgrade, Serbia. Pharmaceutical dosage forms Ceftazidime powder for injection solution was produced by Habit Pharm, Belgrade Serbia; Ceroxim tablets, containg cefuroxime axetil as active component, by Medico Uno d.o.o. Belgrade, Serbia and Longaceph powder for injection solution, which contains ceftriaxone as active component, was produced by Galenika ad. Belgrade, Serbia.

Britton-Robinson (BR) buffer solution, used as supporting electrolyte for voltammetric measurements was prepared in a usual way [28]. All reagents were of analytical grade, and all solutions were prepared in doubly distilled water. Measurements were performed at room temperature.

\subsection{Procedure for sample preparation}

Stock solutions of $1 \times 10^{-3} \mathrm{M} \mathrm{CFZ,} \mathrm{CFXA} \mathrm{and} \mathrm{CTRX} \mathrm{standards} \mathrm{were} \mathrm{prepared} \mathrm{in}$ doubly distilled water and stored at $4{ }^{\circ} \mathrm{C}$. More diluted solutions were prepared daily from the stock solutions.

Ten Ceroxim tablets were weighted and their average mass was calculated. Then all tablets were powdered, and $56.79 \mathrm{mg}$ of powder was dissolved in $25 \mathrm{ml}$ of doubly distilled water, filtrated and used for analysis.

$1 \mathrm{~g}$ of Ceftazidime and $1 \mathrm{~g}$ of Longaceph powder for injection solutions were dissolved in $100 \mathrm{ml}$ of doubly distilled water and appropriate aliquots were used for analysis.

\subsection{Procedure for voltammetric analysis}

Cyclic voltammetry: In electrochemical cell $14.7 \mathrm{ml}$ of BR buffer of different $\mathrm{pHs}$ was transferred, de-aerated for $10 \mathrm{~min}$ with high purity nitrogen, and $0.3 \mathrm{ml}$ of stock solutions were added to make final concentration of cephalosporins $2 \times 10^{-5} \mathrm{M}$. The solution was purged for another $3 \mathrm{~min}$ and cycle voltammograms were recorded with the scan speed of 5-200 $\mathrm{mVs}^{-1}$ and drop size 2 a.u.

DP voltammetry: An aliquot of $15 \mathrm{ml}$ of BR buffer solution was introduced into electrochemical cell and de-aerated with pure nitrogen for $10 \mathrm{~min}$. After $10 \mathrm{~s}$ of rest period, a differential pulse voltammetry was applied in negative direction over the range of $0.0 \mathrm{~V}$ 
to $-1.2 \mathrm{~V}$ vs. $\mathrm{Ag} / \mathrm{AgCl} / 3 \mathrm{M} \mathrm{KCl}$ reference electrode, under the following conditions: scan rate $5 \mathrm{mVs}^{-1}$, pulse amplitude $50 \mathrm{mV}$, pulse width $50 \mathrm{~ms}$. After the background voltammogram had been recorded, aliquots containing 1.5 and $15 \mu \mathrm{L}$ of the stock solution of CFZ, CFXA and CTRX separately, were added to the cell and under the same conditions DP voltammograms were recorded at a new drop. The quantification was performed by standard addition method under the optimized conditions.

\subsection{Procedure for UV-VIS spectrophotometric analysis}

An aliquot of $2 \mathrm{ml}$ of the CTRX stock solution $\left(1 \times 10^{-3} \mathrm{M}\right)$ was transferred to $10 \mathrm{ml}$ calibrated flask and the volume was made up to the mark with BR buffer solution, $\mathrm{pH}$ 3.0. The absorption spectra were recorded from $190 \mathrm{~nm}$ to $400 \mathrm{~nm}$, every five minutes, during 40 minute period, against BR buffer solution, $\mathrm{pH} 3.0$. The absorbance at $195 \mathrm{~nm}$ and $264 \mathrm{~nm}$ was measured at each spectrum.

\section{RESULTS AND DISCUSSION}

The voltammetric behavior of CFZ, CFXA and CTRX, has been examined in $\mathrm{pH}$ range 2.0-8.0 by using $\mathrm{CV}$ and DPV. In acid medium, at $\mathrm{pH} 4$, two well developed reduction peaks are present in the voltammograms of all three cephalosporins. The first one (I), occurred at potentials between $-0.40 \mathrm{~V}$ and $-0.76 \mathrm{~V}$, and the other one (II) at more negative potentials between $-0.90 \mathrm{~V}$ and $-1.10 \mathrm{~V}$ (Fig. 1).

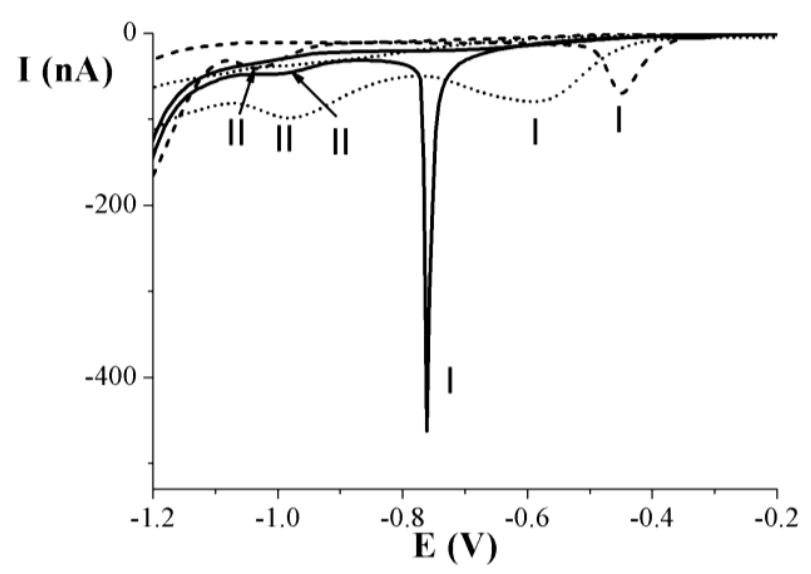

Fig. 1 Representative cyclic voltammograms of $2 \times 10^{-5}$ M CTRX (-), CFZ ( $\left.\cdots\right)$ and CFXA (----), at $\mathrm{pH} 4 ; v=40 \mathrm{mVs}^{-1}$.

According to above mentioned reduction pathway (equations 1-3), it can be assumed that peak I is due to four-electron reduction of methoxy-imino group (in CFXA and CTRX) or substituted methoxy-imino group (in CFZ), and peak II appears as a consequence of the reduction of unsaturated $\mathrm{C}=\mathrm{C}$ bound in cephalosporin ring of all three molecules. 
DP voltammograms of $2 \times 10^{-5} \mathrm{M}$ of CFZ, CFXA and CTRX at $\mathrm{pH} 4$ were recorded in the potential range from $0.0 \mathrm{~V}$ to $-1.2 \mathrm{~V}$. Again, two well developed reduction peaks were obtained in the voltammogram of each cephalosporin. These peaks corresponds to peaks (I) and (II) obtained by cyclic voltammetry.

\subsection{Influence of the $\mathrm{pH}$ of the supporting electrolyte}

The effect of the $\mathrm{pH}$ on the peak potentials and currents of the peak I is presented in Fig. 2. For all investigated drugs peak potential $\left(E_{p}\right)$ is shifted to more negative values with the increase of $\mathrm{pH}$ indicating the involvement of the $\mathrm{H}^{+}$ions in the electron transfer process. Plots of $E_{p}$ versus $\mathrm{pH}$ showed two linear segments (Fig. 2a), with intersection indicating an acid-base equilibrium involving protonation of the methoxy-imino group. At $\mathrm{pH}>7, \mathrm{CFZ}$ and CTRX exhibit the splitting of the peak I, while CFXA even at $\mathrm{pH} 8$ still shows one peak, what is in the accordance with the highest $\mathrm{pH}$ value obtained for intersection of two linear segments.

The current of the cathodic peak I for all three cephalosporins is $\mathrm{pH}$ dependent, as shown in Figure 2b. CFZ and CFXA showed well defined peaks of similar shape and current intensity. However, CTRX peak I shows several times higher intensity and extremely sharp shape. This kind of shape indicates very intense adsorption of the drug molecule on the electrode surface, and according to other authors [24], the reorientation also, what causes very high but not reproducible peak currents.

The peak current of CFZ is increasing with the $\mathrm{pH}$ increase, reaches its maximum at $\mathrm{pH} 3.5$, and then stat to decrease. CFXA shows the highest current values in acid

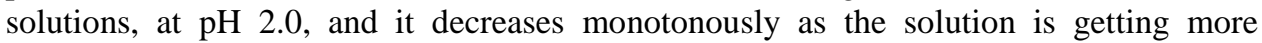
alkaline (Figure 2b).

a)

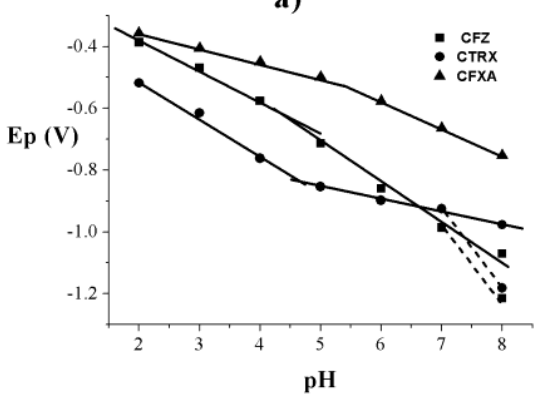

b)

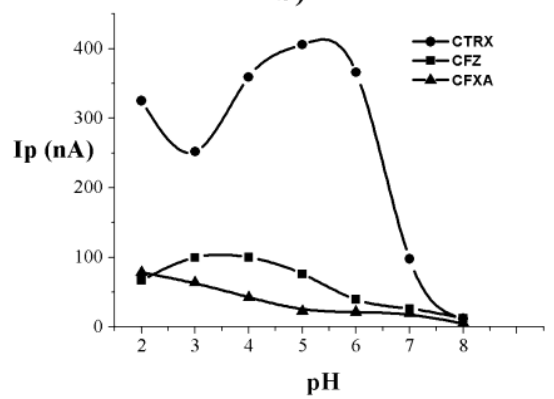

Fig. 2 The influence of the $\mathrm{pH}$ on $\mathrm{CV}$ peak a) potential; b) current response for $2 \times 10^{-5} \mathrm{M}$ of $\operatorname{CTRX}(\bullet), C F Z(\bullet)$ and CFXA $(\boldsymbol{\Delta})$, in BR buffer $\mathrm{pH} 2-8 ; v=40 \mathrm{mV} / \mathrm{s}$.

The nature of the reduction process represented by peak I was studied by following the effect of the scan rate on the peak current. A linear response of Ip with the square root of the scan rate was obtained for CFZ and CFXA at $\mathrm{pH} 3.0$ and the regression equations are: $I p(\mu \mathrm{A})=11.88 v^{1 / 2}\left(\mathrm{~V}^{1 / 2} \mathrm{~s}^{-1 / 2}\right)-0.388(r=0.9996)$, and $I p(\mu \mathrm{A})=6.48 v^{1 / 2}\left(\mathrm{~V}^{1 / 2} \mathrm{~s}^{-1 / 2}\right)$ - $0.023(r=0.9982)$, respectively. On the other hand, for CTRX at the same pH 3.0, the linear response of $I p$ vs. scan rate was obtained, with the following equation: $I p(\mu \mathrm{A})=$ $119.56 v\left(\mathrm{~V} \mathrm{~s}^{-1}\right)+0.582(\mathrm{r}=0.9983)$. 
According to the obtained results it can be assumed that the nature of the cathodic process in acidic solutions for CFZ and CFXA is diffusion controlled, while in the case of CTRX in acid medium, the process is dominantly controlled by the adsorption, (Section 3.2), what is supported by the fact that the slope of the obtained dependence is more than ten times larger comparing to slopes obtained for CFZ and CFXA.

Reduction of the unsaturated $\mathrm{C}=\mathrm{C}$ bond in the $\mathrm{C} 3$ position of all the investigated cephalosporins showed that its peak potential and current are also $\mathrm{pH}$ dependent and the effect of the scan rate shows the usual behavior for the diffusion controlled process. Due to the negative reduction potential of peak (II), and its vicinity to the background discharge current, it was not suitable for analytical purposes.

The irreversibility of all reduction processes represented by peaks I and II was confirmed, since no anodic peak was observed in the whole $\mathrm{pH}$ range.

\subsection{Adsorptive character and chemical stability of ceftriaxone}

A plot of the logarithm of the CV peak current vs. logarithm of the scan rate gives a straight line with different slopes. The slopes obtained at $\mathrm{pH} 3.0$ for CFZ and CFXA are 0.520 and 0.519 respectively, what is close to the theoretical value of 0.5 , expected for the diffusion controlled process [29]. However, at the same $\mathrm{pH} 3.0$ the slope obtained for CTRX is 0.886 (theoretical value for the adsorption controlled process is 1.0 [29]), and thus once again, indicates the strong influence of adsorption.

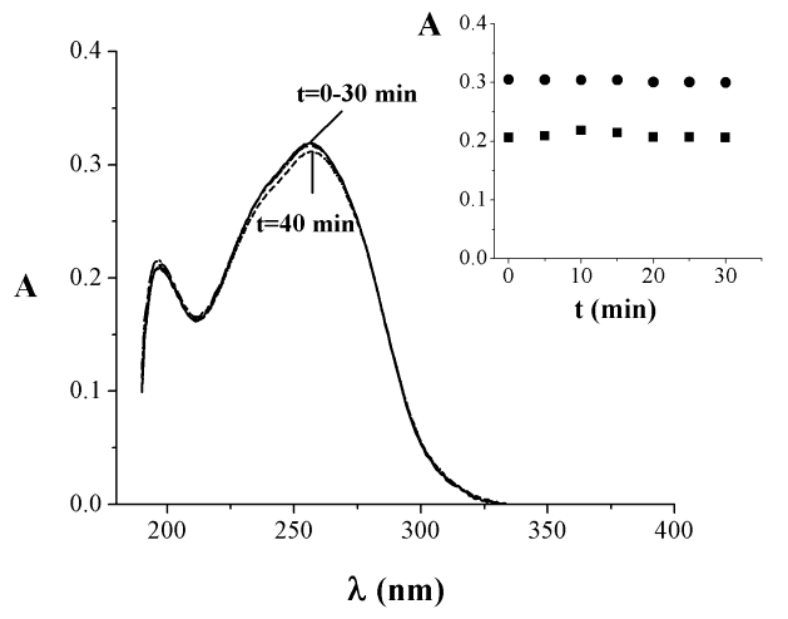

Fig. 3 Absorption spectra of $2 \times 10^{-4} \mathrm{M} \mathrm{CTRX}$ at $\mathrm{pH}=3$ recorded during 0-30 and $40 \mathrm{~min}$ after the solution was prepared. Attached: Absorbance at $195 \mathrm{~nm}(\mathbf{\square})$ and $264 \mathrm{~nm}$ (•) in time

After the $30 \mathrm{~s}$ of preconcentration of the solution containing $5 \times 10^{-7} \mathrm{M}$ CTRX (pH 3), by applying an accumulation potential of $-0.2 \mathrm{~V}$, considerably higher peak current was obtained compared to current without the preconcentration, but the signal showed significant instability. In order to investigate whether the signal instability is caused by the chemical instability of CTRX in acid solution, or simply by the different intensity of cathodic current obtained under different orientation and adsorption of drug molecules, UVVIS absorption spectra were recorded. 
Spectrophotometric analysis showed chemical stability of CTRX in BR buffer pH 3. The absorption spectra of aqueous solution CTRX shows two absorption maxima, at 195 $\mathrm{nm}$ and $264 \mathrm{~nm}$ (Figure 3). During the 30 minutes the spectra was unchanged which is long enough to perform the analysis. According to these results it was suggested that the instability of voltammetric signal is due to adsorption phenomena.

In order to avoid the instability of the voltammetric signal, it was necessary to find the conditions under which the CTRX adsorption is minimized. According to Figure $2 b$ this may be possible in alkaline medium where the CTRX peak current decreases to the values comparable to current obtained by two other investigated cephalosporins. Representative CV and DP voltammograms of CTRX in BR buffer solution at $\mathrm{pH} 8$ are presented in Figure 4. In alkaline medium, at $\mathrm{pH}$ higher then 7, peak I split. DP voltammograms of $5 \times 10^{-6} \mathrm{M}$ were recorded as a function of time, showing that peak Ia, present at the potential of $-0.88 \mathrm{~V}$ is stable and can be used for further analysis. Under these conditions at $\mathrm{pH} 8$, a linear response of $I p$ with the square root of the scan rate was obtained for CTRX (Ia): Ip $(\mu \mathrm{A})=0.86 v^{1 / 2}\left(\mathrm{~V}^{1 / 2} \mathrm{~s}^{-1 / 2}\right)-0.0485(r=0.9992)$ indicating the diffusion controlled process. Also, a plot of the logarithm of the peak Ia current vs. logarithm of the scan rate gives a straight line with decreased slope of 0.513 .

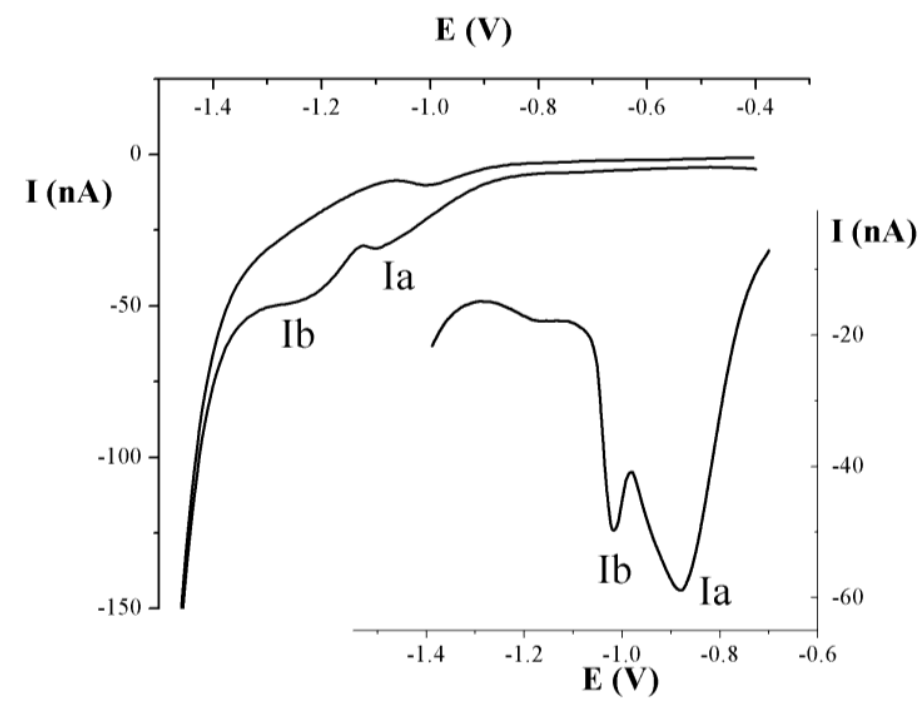

Fig. 4 Representative CV voltammogram of $2 \times 10^{-5} \mathrm{M}$ CTRX, and DP voltammogram of $5 \times 10^{-6} \mathrm{M}$ CTRX at $\mathrm{pH} 8$

\subsection{Method validation}

According to the obtained results, well defined, stable DPV cathodic peaks which are suitable for determination of the drugs were selected. For CFZ peak I at pH $3.5(-0.36 \mathrm{~V})$, for CFXA peak I at pH $2.0(-0.29 \mathrm{~V})$, and for CTRX peak Ia at $\mathrm{pH} 8.0(-0.88 \mathrm{~V})$ were chosen.

Several experimental parameters were examined in developing a suitable analytical procedure for the determination of CFZ, CFXA and CTRX. The study was done with $5 \times 10^{-7} \mathrm{M}$ in BR buffer $\mathrm{pH} 2$ for CFXA, $\mathrm{pH} 3.5$ for CFZ and $\mathrm{pH} 8$ for CTRX. The scan rate $5 \mathrm{mV} / \mathrm{s}$, pulse amplitude of $50 \mathrm{mV}$ and pulse width $50 \mathrm{~ms}$ were further applied. The chosen working condition were drop size 2, without stirring and rest time was $3 \mathrm{~s}$. 
Following DPV onto HMDE linear calibration graphs were obtained for all analytes. Limits of detection (LOD) and quantification (LOQ) were calculated using following equations $\mathrm{LOD}=3 \mathrm{SDa} / \mathrm{b}$ and $\mathrm{LOQ}=10 \mathrm{SDa} / \mathrm{b}$, where $\mathrm{SDa}$ represents the standard deviation of intercept, and $b$ is the slope of the calibration curve [30]. Obtained results are present in Table 2.

Table 2 Analytical parameters for determination of selected cephalosporins

\begin{tabular}{ccccccc}
\hline Drug & $\begin{array}{c}\text { Concentration range } \\
(\mu \mathrm{g} / \mathrm{ml})\end{array}$ & $\begin{array}{c}\text { Regressin eqation } \\
\mathrm{y}(\mu \mathrm{A}), \mathrm{x}(\mu \mathrm{g} / \mathrm{ml})\end{array}$ & $\mathrm{r}$ & $\begin{array}{c}\text { SD } \\
(\mu \mathrm{A})\end{array}$ & $\begin{array}{c}\text { LOD } \\
(\mu \mathrm{g} / \mathrm{ml})\end{array}$ & $\begin{array}{c}\mathrm{LOQ} \\
(\mu \mathrm{g} / \mathrm{ml})\end{array}$ \\
\hline CFZ & $1.2 \times 10^{-1}-6.3 \times 10^{-1}$ & $\mathrm{y}=26.71 \mathrm{x}-1.99$ & 0.9998 & 0.2986 & $4.34 \times 10^{-2}$ & $1.12 \times 10^{-1}$ \\
CFXA & $5.0 \times 10^{-2}-5.0 \times 10^{-1}$ & $\mathrm{y}=47.04 \mathrm{x}+0.43$ & 0.9990 & 0.2171 & $1.38 \times 10^{-2}$ & $4.61 \times 10^{-2}$ \\
& $0.50-5.00$ & $\mathrm{y}=21.62 \mathrm{x}+2.17$ & 0.9994 & 0.9345 & $1.19 \times 10^{-1}$ & $3.97 \times 10^{-1}$ \\
CTRX & $5.5 \times 10^{-2}-4.5 \times 10^{-1}$ & $\mathrm{y}=16.24 \mathrm{x}+0.65$ & 0.9990 & 0.1924 & $1.62 \times 10^{-2}$ & $5.39 \times 10^{-2}$ \\
& $0.45-4.50$ & $\mathrm{y}=8.83 \mathrm{x}+4.76$ & 0.9996 & 0.5354 & $5.48 \times 10^{-2}$ & $1.83 \times 10^{-1}$ \\
\hline
\end{tabular}

Good linearity was obtained for all analyzed cephalosporins. The lowest detection limit, LOD $=1.38 \times 10^{-2} \mu \mathrm{g} / \mathrm{ml}$, is obtained for CFXA. The acceptance criterion for the correlation coefficient was 0.99 or more, and as presented in Table 2, all calibration curves fulfilled this criterion. Comparing the results obtained for CFZ and CFXA in acid medium with results for CTRX obtained in alkaline medium, it is confirmed that $\mathrm{pH} 8$ may be exploited for CTRX determination with equally good sensitivity and correlation coefficient.

The DPV method for determination of CFZ, CFXA and CTRX was tested in terms of repeatability and intra-day precision and accuracy.

Table 3 The precision and accuracy of voltammetric assay for CFZ, CFXA and CTRX standards and pharmaceutical dosage forms Ceftazidime, Ceroxim and Longaceph

\begin{tabular}{lcccc}
\hline Drug & $\begin{array}{c}\text { Added } \\
(\mu \mathrm{g} / \mathrm{ml})\end{array}$ & Found $(\mu \mathrm{g} / \mathrm{ml})$ & $\begin{array}{c}\text { RSD }(\%) \\
(\mathrm{n}=5)\end{array}$ & $\begin{array}{c}\text { Recovery } \\
(\%)\end{array}$ \\
\hline CFZ & 0.204 & 0.197 & 0.36 & 99.01 \\
& 0.306 & 0.302 & 2.47 & 98.04 \\
CFXA & 0.407 & 0.413 & 0.96 & 100.74 \\
& 0.204 & 0.202 & 2.24 & 98.58 \\
CTRX & 0.306 & 0.300 & 2.19 & 98.69 \\
& 0.408 & 0.410 & 1.92 & 101.29 \\
Ceftazidime powder & 0.326 & 0.328 & 1.61 & 100.61 \\
& 0.489 & 0.481 & 0.65 & 98.36 \\
Ceroxim tablets & 0.522 & 0.517 & 1.72 & 99.04 \\
& 0.256 & 0.247 & 2.61 & 96.48 \\
Longaceph powder & 0.384 & 0.394 & 4.93 & 102.60 \\
& 0.306 & 0.295 & 2.53 & 96.29 \\
& 0.409 & 0.418 & 1.15 & 102.20 \\
& 0.277 & 0.288 & 3.21 & 103.97 \\
& 0.415 & 0.400 & 5.11 & 96.47 \\
\hline
\end{tabular}

Repeatability of the results was evaluated by performing five replicate measurements for three different concentrations of all three investigated drugs (Table 3). Mean recoveries of 98.04-101.29\% with RSD 0.36-2.47\% were achieved showing good repeatability of the method. The precision and accuracy of the proposed procedure were investigated 
by intra-day determinations of CFZ, CFXA and CTRX. Nominal acceptance criteria for accuracy and precision was that percent deviation of the mean concentrations falls within $\pm 2 \%$ of the nominal value, and relative standard deviation of each sample must be within $2 \%$. The results are within the acceptance criteria indicating good accuracy of the method proposed.

\subsection{Applicability of the methods}

The proposed DP voltammetric procedure was successfully applied for the direct determination of CFZ, CFXA and CTRX in their pharmaceutical dosage forms: Ceftazidime powder, Ceroxim tablets and Longaceph powder for injection solution, respectively. The amount of the investigated cephalosporin in pharmaceutical formulation was determined by the method of standard addition. Recorded DP voltammograms of Ceftazidime, Ceroxim and Longaceph solutions are presented in Fig 5.

The accuracy and the precision of the method were tested by performing five replicate measurements for two different concentrations of all three investigated pharmaceutical formulations. Mean percentage recoveries of 96.29-103.97 \% with RSD 1.15-5.11\% were obtained indicating that the proposed method is applicable to the analysis of all three investigated cephalosporins (Table 3). The obtained results showed that proposed DPV method could be used for successful determination of investigated cephalosporins in dosage form without any previous sample preparation regardless their compositional complexity.

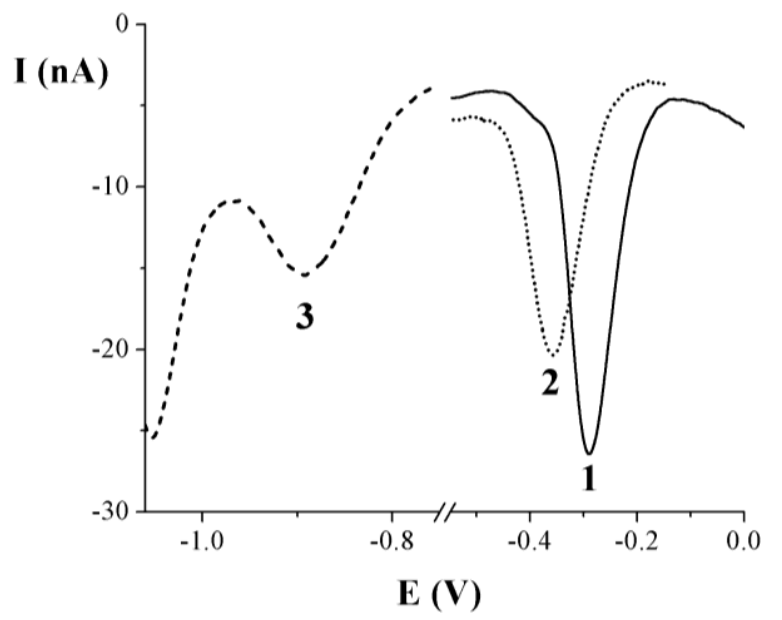

Fig. 5 DP voltammograms of 1) Ceroxim, $\mathrm{pH} 2$; 2) Ceftazidime $\mathrm{pH} 3.5$ and

3) Longaceph solution, pH 8. DPV parameters: pulse amplitude $50 \mathrm{mV}$; pulse width $50 \mathrm{~ms}$; scan rate $5 \mathrm{mV} / \mathrm{s}$.

\section{CONCLUSIONS}

The electrochemical behavior of investigated cephalosporins CFZ, CFXA and CTRX, at the mercury electrode was studied by applying CV and DPV. The results obtained in acid solutions showed that CFZ and CFXA undergo irreversible, diffusion controlled, reduction processes, but CTRX reduction is strongly influenced by the adsorption. Due to the 
adsorption and reorientation of CTRX molecules at the mercury surface, its voltammetric response showed considerabe current instability. This problem was overcame by applying the analysis in alkaline medium, pH 8, where and CTRX undergo irreversible, diffusion controlled, reduction processes. Based on these findings, DPV method for the determination of CFZ and CFXA in acid medium, and for the determination of CTRX in alkaline medium, was developed and suggested. The proposed method is fast, simple, sensitive and precise and can be applied for determination of cephalosporins in pharmaceutical dosage forms: Ceroxim tablets, Ceftazidime powder and Longaceph powder for injection solution. The method is described for assay of pharmaceutical preparations without the necessity for sample pretreatment or time-consuming extraction steps, and therefore can be suggested as a good alternative for the routine quality control of these antibiotics.

\section{REFERENCES}

1. P. Garzone, J. Lyon and V.L. Yu, Third-generation and investigational cephalosporins: I. Structureactivity relationships and pharmacokinetic review. Drug intelligence \& Clinical Pharmacy, 17 (78), 507-515 (1983).

2. Martindale in Reynolds, The Extra Pharmacopeia $29^{\text {th }}$ Edn., Pharmaceutical Press, London, 1989.

3. D.M. Richards and R.N. Brogden, Ceftazidime: A Review of its antibacterial activity, pharmacokinetic properties and therapeutics use, Drugs, 29 (2), 105-161 (1985).

4. J. Airton, Assay of ceftazidime in biological fluids using high pressure liquid chromatography, The Journal of Antimicrobial Chemotherapy, 8 (suppl. B), 227-231 (1981).

5. S.A. Ozkan, Principles and techniques of electroanalytical stripping methods for pharmaceutically active compounds in dosage forms and biological samples. Current Pharmaceutical Analysis, 5, 127-143 (2009).

6. M. Aleksic, V. Kapetanovic, J. Atanackovic, B. Jocić and M. Zećević, Simultaneous determination of cefotaxime and desacetylcefotaxime in urine sample using voltammetric and HPLC methods, Talanta, 77 (1), 131-137 (2008).

7. M. Aleksić and V. Kapetanović, Voltammetric behavior and square-wave voltammetric determination of cefotaxime in urine, Journal Electroanalytical Chemistry, 593 (1-2), 258-266 (2006).

8. M. Aleksić, M. Ilić and V. Kapetanović, Adsorptive properties of cefpodoxime proxetil as a tool for a new method of its determination in urine, Journal of Pharmaceutical and Biomedical Analysis 36 (4), 899-903 (2004).

9. M. Aleksić, Lj. Milovanović and V. Kapetanović, Adsorptive stripping voltammetric determination of cefetamet in human urine, Journal of Pharmaceutical and Biomedical Analysis 32 (4-5), 957966 (2003)

10. T.M. Reddy, M. Sreedhar, and S.J. Reddy, Voltammetric behavior of Cefixime and Cefpodoxime proxetil and determination in pharmaceutical formulations and urine, Journal of Pharmaceutical and Biomedical Analysis 31 (4), 811-818 (2003).

11. E. Muñoz, L. Camacho, L.J. Avila and F. Garcia-Blanko, Cyclic and linear sweep voltammetry of cefazolin and cefmetazole: Electroanalytical applications, Analyst, 114 (12), 1611-1615 (1989).

12. S. Altinoz, A. Temizer and S. Beksac, Determination of ceftriaxone in biological material by differential-pulse adsorptive stripping voltammetry, Analyst, 115 (6), 873-874 (1990).

13. S. Altinoz, D. Ozer, A. Temizer and N. Yuksel, Determination of ceftriaxone in aqueous humor and serum samples of differential-pulse adsorptive stripping voltammetry, Analyst 119 (7), 1575-1577 (1994).

14. V.S. Ferreira, V.B. Zanoni, M. Furlan and A.G. Fogg, Differential pulse polarographic determination of ceftazidime in urine samples with and without prior extraction, Analytica Chimica Acta, 351 (1-3), 105114 (1997).

15. P. Zuman, V. Kapetanovic and M. Aleksic, Recent developments in electroanalytical chemistry of cephalosporins and cefamycins, Analytical letters 33 (14), 2821-2857 (2000).

16. E. Munoz, J.L. Avila, J. Perez Doctor and L. Camacho, The transfer coefficient of the electrochemical reduction of cephalosporins and cefamycins. Electroanalysis, 5 (4), 325-331 (1993). 
17. G.V.S. Reddy, M.V. Narasimha and S.J. Reddy, Polarographic reduction behavior of some potential antibiotic cephalosporins, International Journal of Pharmacy and Pharmaceutical Sciences, 2 (4), 190193 (2010).

18. V. Kapetanović, M. Aleksić AND P. Zuman, Two step reduction of the O-methyloxime grouping in the antibiotic cefetamet, Journal of Electroanalytical Chemistry, 507 (1-2), 263-269 (2001).

19. M. Aleksić, V. Kapetanović and P. Zuman, Polarographic and voltammetric behavior of the antibiotic cefetamet; Reduction of the methoxyimino group, Collection of Czechoslovakian Chemical Communication, 69 (7), 1429-1442 (2004).

20. V.S. Ferreira, M.V.B. Zanoni and A.G. Fogg, Cathodic stripping voltammetric determination of ceftazidime in urine at a hanging mercury drop electrode, Microchemical Journal, 57 (1), 115-122 (1997).

21. V.S. Ferreira, M.V.B. Zanoni and A.G. Fogg, Indirect cathodic-stripping voltammetric determination of ceftazidime as a mercury salt, Analytica Chimica Acta, 367 (2), 255-259 (1998).

22. V.S. Ferreira, M.V.B. Zanoni and A.G. Fogg, Cathodic stripping voltammetric determination of ceftazidime with reactive accumulation at a poly-L-lysine modified hanging mercury drop electrode, Analytica Chimica Acta, 384, 159-166 (1999).

23. B. Ogorevc, V. Hudnik and S. Gomišček, Polarographic analysis of some cephalosporin antibiotics. Fresenius' Zeitschrift für Analytische Chemie, 330 (1), $59-64$ (1988).

24. N.A. El-Maali, A.M.M. Ali and M.A. Ghandour, Electrochemical reduction and oxidation of two cephalosporin antibiotics: ceftriaxone and cefoperazone, Electroanalysis, 5 (7), 599-604 (1993).

25. B. Ogorevc, M. R. Smyth, V. Hudnik and S. Gomišček, in: Electrochemistry, Sensors and Analysis, M. R. Smyth, J. G. Vos, Eds., Elsevier, Amsterdam, 403-409 (1986)

26. G.V.S. Reddy and S.J. Reddy, Estimation of cephalosporin antibiotics by differential pulse polarography, Talanta, 44 (4), 627-631 (1997)

27. S. Majdi, A. Jabbari, H. Heli, H. Yadegari, A.A. Moosavi-Movahedi and S. Haghgoo, Electrochemical oxidation and determination of ceftriaxone on a glassy carbon and carbon-nanotube-modified glassy carbon electrodes. Journal of Solid State Electrochemistry, 13 (3), 407-416 (2009).

28. D.D. Perrin and B. Dempsey, Buffers for $\mathrm{pH}$ and metal ion control, Chapman and Hall, London, 1974

29. E. Laviron, L. Roullier and C. Degrand, A multilayer model for the study of space distributed redox modified electrodes: Part II. Theory and application of linear potential sweep voltammetry for a simple reaction. Journal of Electroanalytical Chemistry, 112 (1), 11-23 (1980).

30. J. Ermer and J.H.B. McMiller, Method validation in pharmaceutical Analysis, Wiley-VCH, Weinheim, 2005.

\section{ELEKTROHEMIJSKO PONAŠANJE I PRIMENA DIFERENCIJALNO PULSNE VOLTAMETRIJE ZA ODREĐIVANJE CEFTAZIDIMA, CEFUROKSIM-AKSETILA I CEFTRIAKSONA}

Voltametrijsko ponašanje tri cephalosporina: ceftazidima, cefuroksim-aksetila i ceftriaksona ispitivano je cikličnom $(C V)$ i diferencijalno pulsnom (DPV) voltametrijom u pH oblasti od 2,0 do 8,0 na visećoj živnoj kapi. Razmatrani su uticaji pH osnovnog elektrolita $i$ brzine promene potencijala na vrednost stuje i potencijala voltametrijskih pikova. Rezultati dobijeni u kiseloj sredini su pokazali da je redukcija ceftazidima i cefuroksim-aksetila difuziono kontrolisan proces, a da je u slučaju ceftriaksona priroda redukcije na elektrodi jako zavisna od adsorpcije. Posledica adsorpcije i reorijentacije molekula ceftriaksona na površini elektrode je nestabilnost $i$ nereproduktivnost voltametrijskog signala što onemogućava određivanje cefriaksona u kiseloj sredini. Intenzitet adsorpcije ceftriaksona opada sa porastom $\mathrm{pH}$ i pri $\mathrm{pH}>7$ njegova redukcija postaje difuzijom kontrolisan proces. Na osnovu ovih rezultata predložena je $i$ validirana DPV metoda za određvanje ceftazidima na $\mathrm{pH}$ 2,0, cefuroksimaksetila na $\mathrm{pH}$ 3,5 i ceftriaksona na $\mathrm{pH} 8,0$. Određene su vrednosti opsega linearnosti, granice detekcije $i$ određivanja. Metoda je uspešno primenjena za određivanje ovih cefalosporina u farmaceutskim doziranim oblicima i to u Ceroxim tabletama i Ceftazidim i Longaceph prašku za injekcione rastvore.

Ključne reči: Ceftazidim, cefuroksim-aksetil, ceftriakson, voltametrija, adsorpcija, određivanje. 